\title{
Physiological profile of world-class high-altitude climbers
}

\author{
OSWALD OELZ, HANS HOWALD, PIETRO E. DI PRAMPERO, HANS HOPPELER, \\ HELGARD CLAASSEN, ROLF JENNI, ALBERT BÜHLMANN, GUIDO FERRETTI, \\ JEAN-CLAUDE BRÜCKNER, ARSENIO VEICSTEINAS, MARISTELLA GUSSONI, \\ AND PAOLO CERRETELLI \\ University Hospital, Zurich; Research Institute, Swiss School for Physical Education \\ and Sports, Magglingen; Department of Physiology, Centre Medical Universitaire, Geneva; \\ Department of Anatomy, University of Bern, Bern, Switzerland; and \\ Department of Physiology, University of Brescia, Brescia, Italy
}

Oelz, Oswald, Hans Howald, Pietro E. Di Prampero, Hans Hoppeler, Helgard Claassen, Rolf Jenni, Albert Bühlmann, Guido Ferretti, Jean-Claude Brückner, ARSenio Veicsteinas, Maristella Gussoni, and Paolo CerRETELLI. Physiological profile of world-class high-altitude climbers. J. Appl. Physiol. 60(5): 1734-1742, 1986.-The functional characteristics of six world-class high-altitude mountaineers were assessed 2-12 mo after the last high-altitude climb. Each climber on one or several occasions had reached altitudes of $8,500 \mathrm{~m}$ or above without supplementary $\mathrm{O}_{2}$. Static and dynamic lung volumes and right and left echocardiographic measurements were found to be within normal limits of sedentary controls (SC). Muscle fiber distribution was $70 \%$ type I, $22 \%$ type IIa, and $7 \%$ type IIb. Mean muscle fiber crosssectional area was significantly smaller than that of SC $(-15 \%)$ and of long-distance runners (LDR, -51\%). The number of capillaries per unit cross-sectional area was significantly greater than that of SC $(+40 \%)$. Total mitochondrial volume was not significantly different from that of SC, but its subsarcolemmal component was equal to that of LDR. Average maximal $\mathrm{O}_{2}$ consumption was $60 \pm 6 \mathrm{ml} \cdot \mathrm{kg}^{-1} \cdot \mathrm{min}^{-1}$, which is between the values of SC and LDR. Average maximal anaerobic power was $28 \pm 2.5 \mathrm{~W} \cdot \mathrm{kg}^{-1}$, which is equal to that of SC and $40 \%$ lower than that of competitive high jumpers. All subjects were characterized by resting hyperventilation both in normoxia and in moderate (inspired $\mathrm{O}_{2}$ partial pressure $=77$ Torr) hypoxia resulting in higher oxyhemoglobin saturation levels in hypoxia. The ventilatory response to four tidal volumes of pure $\mathrm{O}_{2}$ was similar to that of SC. It is concluded that elite high-altitude climbers do not have physiological adaptations to high altitude that justify their unique performance.

high-altitude elite climbers; muscle morphometry and mitochondria; heart dimensions by echocardiography; maximal aerobic and anaerobic power; chemoreflex respiratory drive

REINHOLD MESSNER AND PETER HABELER, on May 8, 1978 , proved the fallacy of the widely accepted dogma that altitudes over $8,500 \mathrm{~m}$ could not be reached without supplemental $\mathrm{O}_{2}(16,25)$. Until then, despite a few dissenting opinions, mostly from climbers $(20,26)$, most respiratory physiologists were convinced that arterial $\mathrm{O}_{2}$ partial pressures on the order of $\sim 35$ Torr or below, were incompatible, if not with life, with the strenuous effort required to climb the highest summits of the Earth. Since the $\mathrm{O}_{2}$ partial pressure on Mt. Everest was found to be $\sim 35$ 'Torr (35), to explain Messner and Habeler's exceptional feat, it had been suggested that these particular climbers might be extraordinary in their capacity to take up and/or to utilize $\mathrm{O}_{2}(32)$. It was postulated that climbing without bottled $\mathrm{O}_{2}$ to the top of Mt. Everest might only be possible for individuals characterized by an extremely high maximal aerobic power. Alternatively, it was hypothesized that these climbers could be penalized less than others in terms of arterial $\mathrm{O}_{2}$ desaturation, perhaps as a consequence of an enhanced hypoxic ventilatory drive $(30,31)$.

The fact that after the first successful attempt by Messner and Habeler a few more climbers could repeat the same performance has prompted us to investigate whether the above hypotheses were tenable. The aim of the present study was to investigate the physiological characteristics of six world-class high-altitude climbers. Specifically, muscle fiber types and muscle morphometry, maximal aerobic and anaerobic power, and ventilatory control were assessed.

\section{MATERIALS AND METHODS}

\section{Subjects}

Six climbers who had reached at least one of the four highest peaks in the world (Everest 8,848 m, K2 8,611 $\mathrm{m}$, Kanchenjunga $8,596 \mathrm{~m}$, Lhotse $8,560 \mathrm{~m}$ ) without bottled $\mathrm{O}_{2}$ volunteered for this study and gave informed consent (Table 1). Among them were the first three Caucasians to climb Mt. Everest without supplemental $\mathrm{O}_{2}$. All grew up in small villages below $1,150 \mathrm{~m}$ altitude and started mountaineering in their childhood. All had an impressive record of long and difficult alpine ascents. Four were professional mountaineers; the other two spent their holidays in the mountains. Three had suffered from complicated bone fractures in the past; two had undergone frostbite resulting in partial loss of toes and fingers. Three had never experienced any symptoms of 
acute mountain sickness; two had developed light headache during earlier high-altitude exposures. One $(P H)$ had suffered from frequent headache and occasional vomiting above $5,300 \mathrm{~m}$ and had experienced symptoms of high-altitude cerebral edema once while climbing at $6,400 \mathrm{~m}$ three years after his successful ascent of Everest without $\mathrm{O}_{2}$. Five had experiences on 8,000 -m peaks before they climbed higher than $8,500 \mathrm{~m}$ without supplemental $\mathrm{O}_{2}$. One had never been above $4,800 \mathrm{~m}$ before he reached the summit of Mt. Everest without $\mathrm{O}_{2}$ in the fall of 1978. Two earlier had climbed Mt. Everest with $\mathrm{O}_{2}$ and later without. The subjects were studied 2-12 mo after their last high-altitude exposure, i.e., presumably at a time when most physiological changes induced by acclimatization had disappeared. Different measurements were made at each of three different laboratories in Zurich, Magglingen, and Geneva (Switzerland) on two consecutive days. One climber $(R M)$ was studied in Geneva one year after the studies in Zurich and Magglingen.

\section{Methods and Experimental Procedure}

Physical examination of subjects, routine lung function tests, and cardiac structure and function by echocardiography. The physical examination of the subjects was carried out according to the standard routine of the Department of Medicine, Zurich University Hospital. The pulmonary function tests included the measurements of total lung capacity by the dilution technique, forced vital capacity, and forced expiratory volume in 1.0 s. The results were expressed as absolute values and as percent of the reference values predicted on the basis of sex, age, weight, and height (5).

M-mode echocardiograms were carried out in the left lateral decubital position with a $2.25-\mathrm{MHz}$ echotransducer (Organon Teknika). The tracings were recorded on a strip-chart recorder (Honeywell). An aortoapical sweep was obtained in all patients. Aorta, left atrium, end-systolic, and end-diastolic dimensions of the left ventricle, end-diastolic septum, and posterior wall thickness were measured by standard methods (14).

Two-dimensional echocardiograms were obtained using an ultrasonic phased-array sector-scanner equipment (Diasonic V $3400 \mathrm{R}$ ) with a $2.2-\mathrm{MHz} 32$-element or a $3.5-\mathrm{MHz}$ 20-element transducer. The echocardiograms and a peripheral lead of the electrocardiogram were recorded on a 1-in. videotape (Grundig recorder BK 204) for later playback for which a high-resolution TV monitor (Telektronix 632) was used. The dimensions of the

TABLE 1. Subjects climbing history

\begin{tabular}{|c|c|c|c|c|c|}
\hline \multirow{2}{*}{ Subj } & \multirow{2}{*}{$\begin{array}{l}\text { Country of } \\
\text { Origin }\end{array}$} & \multirow{2}{*}{$\begin{array}{c}\text { Age, } \\
\mathrm{yr}\end{array}$} & \multicolumn{2}{|c|}{$\begin{array}{c}\text { Peaks } \\
>8,500 \mathrm{~m}\end{array}$} & \multirow{2}{*}{$\begin{array}{c}\text { Peaks } \\
8,000-8,500 \mathrm{~m} \\
\text { Without } \\
\mathrm{O}_{2}\end{array}$} \\
\hline & & & $\begin{array}{c}\text { Without } \\
\mathrm{O}_{2}\end{array}$ & $\begin{array}{c}\text { With } \\
\mathrm{O}_{2}\end{array}$ & \\
\hline$R M$ & Italy & 39 & 4 & & 10 \\
\hline$M D$ & Germany & 50 & 2 & 1 & 3 \\
\hline$D S$ & UK & 42 & 1 & 1 & 2 \\
\hline$P H$ & Austria & 41 & 1 & & 1 \\
\hline$H E$ & Germany & 38 & 1 & & 1 \\
\hline$F M$ & Italy & 34 & 1 & & 1 \\
\hline
\end{tabular}

right atrium as well as those of the right ventricle were obtained in the four-chamber view (2). The long and the short axis of the right atrium were measured in the endsystolic position. The medium short axis of the right ventricle was measured in the end-diastolic position. The values of 20 untrained healthy subjects used as control were obtained in the same laboratory (22). The diameter of the pulmonary artery was compared with that of the aorta in a parasternal short axis view at the level of the aorta and of the pulmonary artery.

Muscle fiber types and muscle morphometry. A needle biopsy $(50-100 \mathrm{mg})$ was taken at midthigh level from the vastus lateralis muscle in five of the six subjects prior to the treadmill running test. One part of the sample was immediately frozen in isopentane cooled in liquid $\mathrm{N}_{2}$. Serial cryostat cross sections $(12 \mu \mathrm{m})$ of this material were used for the identification of fiber types I, IIa, and IIb by histochemical staining of adenosine triphosphatase after acid and alkaline preincubation at $\mathrm{pH} 4.3,4.6$, and 10.4 (27). The remainder of the sample was processed for electron microscopy by fixation for $1 \mathrm{~h}$ in a $6.25 \%$ solution of glutaraldehyde, as previously described in detail (19). Micrographs for morphometry were taken on $35-\mathrm{mm}$ films using a Philips EM 300 electron microscope. Stereological analysis was performed on two randomly chosen blocks from each biopsy. The orientation of the sections was slightly oblique with regard to the fiber axis. Since, as is well known, mitochondria cluster around the $\mathrm{Z}$ lines, perpendicular sections could over or underestimate the actual mean mitochondrial volume density in the fibers. Calculations have shown that an angle between 66 and $88^{\circ}$ is the most appropriate for minimizing sampling errors (33). Numbers of capillaries and fibers per unit area as well as the average fiber crosssectional area were estimated at a final magnification of $\times 1,500$, as previously described (36). Since the orientation of the cross sections was not at a right angle with the axis of the fibers, the average cross-sectional area is slightly $(<10 \%)$ overestimated. Eight micrographs per block and hence 16 micrographs per biopsy were taken in consecutive frames of slotted grids yielding $>100$ muscles fiber profiles for analysis in each subject. A final magnification of $\times 24,000$ was used for estimating the volumes of mitochondria, intracellular lipids, myofibrils, and residual sarcoplasmic components per unit volume of muscle fiber. Twenty micrographs per block and hence 40 micrographs per biopsy were obtained with a systematic sampling procedure in consecutive frames of 200square mesh grids. Contact prints of the $35-\mathrm{mm}$ films were projected on a screen fitted with quadratic line grids. Point counting was performed with a A100 grid (100 test points) for the low magnification and with a B36 grid (144 test points) for the high magnification (33). Parameter estimates were obtained according to standard stereological procedures (33).

Maximal $\mathrm{O}_{2}$ consumption and efficiency of locomotion. $\mathrm{O}_{2}$ consumption $\left(\dot{\mathrm{V}}_{2}\right)$, heart rate (HR), and venous blood lactate concentration $\left(\left[\mathrm{La}_{b}\right]\right)$ were determined on the treadmill. Two protocols were used: walking at speeds from 2.7 to $5.0 \mathrm{~km} \cdot \mathrm{h}^{-1}$ on a $+35 \%$ grade and running at speeds from 6 to $13.5 \mathrm{~km} \cdot \mathrm{h}^{-1}$ on a $+10 \%$ grade in four 
to six increasing steps in two different laboratories. For each series the subjects performed four to six runs at increasing speed up to individual maximum. This was established by 1) the lack of increase of $\mathrm{V}_{2}$ between two successive increasing work loads, 2) the attainment of maximal $\mathrm{HR}\left(\Delta \mathrm{HR}<5\right.$ beats $\left.\left.\cdot \mathrm{min}^{-1}\right), 3\right)\left[\mathrm{La}_{\mathrm{b}}\right]$ exceeding $7 \mathrm{mM}$ at the end of the highest work load, and 4) voluntary exhaustion. In the walking series, $\mathrm{Vo}_{2}$ was determined by conventional open-circuit method from the 4 th to the 6 th $\min$ of each constant-intensity load. A resting period of about $20 \mathrm{~min}$ was allowed between successive measurements. In the running series, after 5 min at the initial speed of $6 \mathrm{~km} \cdot \mathrm{h}^{-1}$, the speed was increased by $1.5-\mathrm{km} \cdot \mathrm{h}^{-1}$ steps every $3 \mathrm{~min}$, and $\dot{\mathrm{V}} \mathrm{o}_{2}$ was measured by the open-circuit method over consecutive 30 -s periods. The mean of the last three measurements was taken as the $\dot{\mathrm{VO}}_{2}$ corresponding to the tested speed. Both in walking and running, the mechanical efficiency of locomotion was calculated from the ratio of the potential energy changes to the energy consumption above resting, on the assumption that $1 \mathrm{ml} \mathrm{O}_{2}=20.9 \mathrm{~J}$ [for a respiratory quotient $(R Q)=0.96 \mathrm{~J}$. In both series of measurements, HR was determined during the last minute of each run, and blood samples were drawn from the antecubital vein or from the ear lobe at the end of each run for $L a_{b}$ enzymatic determination.

Maximal anaerobic power. The maximal anaerobic power $\left(\dot{\mathrm{w}}_{\max }\right)$ was calculated from the vertical force $\left(F_{\mathrm{v}}\right)$ exerted on a force platform during a standing high jump off both feet, as originally proposed by Davies and Rennie (10). Since the mass of the subject is known, the vertical velocity of the center of gravity of the body can be obtained by time integration of the $F_{\mathrm{v}}$ vs. time curve. The instantaneous power output throughout the jump is then calculated from the product of the $F_{\mathrm{v}}$ times the vertical velocity. The integrated mean of the instantaneous power yields the maximal power output (i.e., $\dot{\mathrm{w}}_{\max }$ ).

The force platform consisted in a rigid light-weight $(\sim 8 \mathrm{~kg})$ honeycomb aluminum square plate $(70 \times 70 \mathrm{~cm})$ mounted on a rigid frame. The vertical forces were monitored by means of eight strain gauges located at the four corners of the frame. The resonant frequency of the system was $50 \mathrm{~Hz}$. The summated output of the strain gauges was stored on magnetic tape for subsequent processing.

Each subject performed four maximal high jumps from a $90^{\circ}$ knee angle position. To minimize the recovery of elastic energy, the subjects were instructed to avoid any prejump countermovement. The highest recorded $\dot{\mathrm{w}}_{\max }$ value was retained. The control group consisted of four sex- and age-matched sedentary subjects.

Ventilatory control, oxyhemoglobin saturation, and heart rate. Indexes of the individual chemoreflex drive were determined for the six investigated climbers and for three control subjects [untrained unacclimatized males in the age range $27-44 \mathrm{yr}$ and characterized by a maximal $\mathrm{O}_{2}$ consumption $\left(\mathrm{V}_{2} \mathrm{O}_{2 a x}\right)$ of $\left.39-42 \mathrm{ml} \cdot \mathrm{kg}^{-1} \cdot \mathrm{min}^{-1}\right]$ following the experimental protocol provided by S. Lahiri. According to this procedure, the subjects breathed ambient air [inspired $\mathrm{O}_{2}$ partial pressure $\left(\mathrm{PI}_{\mathrm{O}_{2}}\right)=152$ Torr $)$ or a hypoxic mixture $\left(\mathrm{PI}_{\mathrm{O}_{2}}=77\right.$ Torr $)$ both at rest and while performing a $90-\mathrm{W}$ cycloergometric exercise $\left(\mathrm{V}_{2}\right.$ of $\sim 1.4 \mathrm{l} \cdot \mathrm{min}^{-1}$, i.e. $\sim 0.35$ of the average $\left.\dot{\mathrm{V}}_{2 \text { max }}\right)$. The two protocols were administered on different occasions.

Pulmonary ventilation on a breath-by-breath basis ( $\dot{\mathrm{V} E}$ at BTPS), end-tidal $\mathrm{CO}_{2}$ partial pressure $\left(\mathrm{PET}_{\mathrm{CO}_{2}}\right)$ by $\mathrm{CO}_{2}$ analyzer (BINOS 1, Leybold-Heraeus, Hanau, FRG), arterial $\mathrm{O}_{2}$ saturation $\left(\mathrm{HbO}_{2}\right)$ by ear oximetry (BIOX II, Biox Technology, Boulder, CO), and HR by electrocardiography were monitored continuously until a steady state was attained. Resting VE was measured on repeated occasions over $15-20 \mathrm{~min}$. This should minimize possible bias caused by the experimental manipulation. Subsequently, four breaths of $100 \% \mathrm{O}_{2}$ were administered at three timed intervals of 4-5 min and the $\dot{V E}$, PET $_{\mathrm{CO}_{2}}$, $\% \mathrm{HbO}_{2}$, and $\mathrm{HR}$ transients were recorded on a polygraph (Hewlett-Packard, Waltham, MA). Tidal volume (VT) and $\mathrm{PET}_{\mathrm{CO}_{2}}$ averages were obtained for the two groups of subjects following the $\mathrm{O}_{2}$ test. $\dot{\mathrm{V}} \mathrm{E}$ averaging after $\mathrm{O}_{2}$ substitution was made for the breath number rather than their timing. The mean $\dot{V}_{E}$ change in respect to the reference values is expressed as the mean $\Delta \mathrm{VE} . \% \mathrm{HbO}_{2}$ and $\mathrm{HR}$ were recorded every $10 \mathrm{~s}$ following the $\mathrm{PI}_{\mathrm{O}_{2}}$ change, and the average changes compared with the controls were calculated in the same manner as for $\dot{V} E$.

\section{RESULTS AND DISCUSSION}

\section{Physical and Clinical Examination}

The clinical examination of the six subjects showed average normotrophic endurance-type athletes with particularly well developed limb muscles.

Two had suffered from previous toe and finger amputations, one had bilateral inguinal hernias and multiple subcutaneous lipoma, and another had a large hydronephrotic cyst replacing one kidney (checked by abdominal ultrasound), which was surgically removed 3 mo before successfully climbing an 8,000-m peak without $\mathrm{O}_{2}$.

The basic physical and physiological characteristics of the subjects are shown in Table 2.

The results of standard spirometric measurements appear in Table 3 . All but one subject $(R M)$ had respiratory volumes slightly above the predicted values, which may favor high-altitude adaptation (17). The potential disadvantage of the lung volumes lower than expected in subject $R M$ appears to be compensated for by the in-

TABLE 2. Anthropometric and basic physiological characteristics of subjects

\begin{tabular}{lcccccccc}
\hline Subj & $\mathrm{Ht}, \mathrm{cm}$ & $\begin{array}{c}\mathrm{Wt}, \\
\mathrm{kg}\end{array}$ & $\begin{array}{c}\mathrm{BP}_{\text {syst, }} \\
\mathrm{mmHg}\end{array}$ & $\begin{array}{c}\mathrm{BP}_{\text {diast }}, \\
\mathrm{mmHg}\end{array}$ & $\begin{array}{c}\mathrm{HR}_{\text {rest }} \\
\mathrm{min}^{-1}\end{array}$ & $\begin{array}{c}\mathrm{C} / \mathrm{T} \\
\text { Ratio }\end{array}$ & $\begin{array}{c}\mathrm{Hct}, \\
\%\end{array}$ & $\begin{array}{c}{[\mathrm{Hb}],} \\
\mathrm{g} / 100 \mathrm{ml}\end{array}$ \\
\hline$R M$ & 179.0 & 69.0 & 105 & 75 & 56.0 & 0.45 & 42.0 & 15.2 \\
$M D$ & 170.0 & 68.0 & 110 & 80 & 36.0 & 0.47 & 43.0 & 14.3 \\
$D S$ & 182.0 & 81.0 & 120 & 80 & 66.0 & 0.39 & 39.0 & 13.3 \\
$P H$ & 174.0 & 60.0 & 110 & 80 & 60.0 & 0.41 & 49.0 & 16.4 \\
$H E$ & 178.0 & 79.0 & 120 & 85 & 56.0 & 0.49 & 43.0 & 14.8 \\
$F M$ & 173.0 & 70.0 & 110 & 75 & 56.0 & 0.43 & 47.0 & 15.7 \\
& & & & & & & & \\
Mean & 176.0 & 71.2 & 113 & 79 & 55.0 & 0.44 & 43.8 & 15.0 \\
$\pm \mathrm{SD}$ & \pm 4.4 & \pm 7.7 & \pm 6 & \pm 4 & \pm 10.1 & \pm 0.04 & \pm 3.6 & \pm 1.1 \\
\hline
\end{tabular}

$\mathrm{BP}_{\text {syst }}$, systolic blood pressure; $\mathrm{BP}_{\text {diast }}$, diastolic blood pressure; $\mathrm{HR}_{\text {rest }}$, heart rate at rest; $\mathrm{C} / \mathrm{T}$ ratio, cardiothoracic ratio; Hct, hematocrit; $[\mathrm{Hb}]$, hemoglobin concentration. 
TABLE 3. Spirometric data of subjects

\begin{tabular}{|c|c|c|c|c|c|c|}
\hline \multirow{2}{*}{ Subj } & \multicolumn{2}{|c|}{ TLC } & \multicolumn{2}{|c|}{ FVC } & \multicolumn{2}{|c|}{$\mathrm{FEV}_{1.0}$} \\
\hline & $\mathrm{ml}$ & $\%$ Pred & $\mathrm{ml}$ & $\%$ Pred & $\mathrm{ml}$ & \%Pred \\
\hline$R M$ & 6,810 & 94.0 & 4,650 & 83.0 & 3,700 & 95.0 \\
\hline$M D$ & 7,160 & 111.0 & 5,250 & 112.0 & 4,200 & 127.0 \\
\hline$D S$ & 8,280 & 110.0 & 6,050 & 105.0 & 4,450 & 110.0 \\
\hline$P H$ & 7,200 & 105.0 & 5,550 & 106.0 & 4,200 & 114.0 \\
\hline$H E$ & 8,720 & 121.0 & 6,400 & 115.0 & 5,250 & 135.0 \\
\hline$F M$ & 7,270 & 108.0 & 5,550 & 106.0 & 4,900 & 132.0 \\
\hline Mean & 7,573 & 108.2 & 5,575 & 104.5 & 4,450 & 118.8 \\
\hline$\pm \mathrm{SD}$ & \pm 748 & \pm 8.8 & \pm 611 & \pm 11.3 & \pm 553 & \pm 15.3 \\
\hline
\end{tabular}

TLC, total lung capacity; FVC, forced vital capacity; $\mathrm{FEV}_{1.0}$, forced expiratory volume in $1.0 \mathrm{~s}$; \% Pred, percentage of predicted values.

TABLE 4. Two-dimensional echocardiographic data of right heart

\begin{tabular}{lrrrrr}
\hline Subj & $\begin{array}{c}\mathrm{HR}, \\
\mathrm{min}^{-1}\end{array}$ & $\begin{array}{c}\text { RA Long, } \\
\mathrm{cm}\end{array}$ & $\begin{array}{c}\text { RA Short, } \\
\mathrm{cm}\end{array}$ & $\begin{array}{c}\mathrm{RV}, \\
\mathrm{cm}\end{array}$ & PA \\
\hline$R M$ & 53.0 & 4.5 & 3.5 & 3.5 & $<\mathrm{AO}$ \\
$M D$ & 40.0 & 4.5 & 3.5 & 3.3 & $<\mathrm{AO}$ \\
$D S$ & 78.0 & 5.3 & 5.0 & 3.3 & $<\mathrm{AO}$ \\
$P H$ & 53.0 & 4.8 & 3.5 & 3.2 & $<\mathrm{AO}$ \\
$H E$ & 60.0 & 5.0 & 3.5 & 4.0 & $<\mathrm{AO}$ \\
$F M$ & 57.0 & 4.7 & 3.6 & 3.8 & $<\mathrm{AO}$ \\
Mean & 56.8 & 4.8 & 3.8 & 3.5 & \\
\pm SD & \pm 12.4 & \pm 0.3 & \pm 0.6 & \pm 0.3 & \\
Normal & & $<5.0$ & $<4.1$ & $<4.0$ & $<\mathrm{AO}$
\end{tabular}

$\mathrm{HR}$, heart rate; RA long, right atrium long axis; RA short, right atrium short axis; $R V$, right ventricle short axis; $P A$, pulmonary artery diameter; $\mathrm{AO}$, aorta; normal, normal limits for 20 healthy untrained men.

creased resting ventilation (17.5 compared with an average $13.71 \cdot \mathrm{min}^{-1}$ for the other 5 climbers at a $\mathrm{PI}_{\mathrm{O}_{2}}=77$ Torr). Schoene (30) also found lung volumes lower than predicted in a few climbers who had reached the summit of Everest with $\mathrm{O}_{2}$ or $\mathrm{K} 2$ partly without $\mathrm{O}_{2}$. All subjects had low resting pulse rates and blood pressures (see Table 2). The electrocardiogram showed sinus bradycardia and no signs of either left or right ventricular hypertrophy. The chest X-ray films did not disclose any abnormalities, and the mean cardiothoracic ratio was $\sim 0.44$ (see Table $2)$.

Two-dimensional echocardiography disclosed normal dimensions of the right heart in five subjects (Table 4). In one of the climbers $(D S)$ an unexplained dilatation of the right atrium with a normal tricuspid valve was found. There were no signs of right ventricular hypertrophy in any subjects, and the diameters of the pulmonary arteries were smaller than those of the aorta. This, assuming a transient increase of pulmonary artery pressure during high-altitude exposure as found in most acclimatized lowlanders, would be indicative of a rapid normalization. This finding is at variance with the persisting pulmonary hypertension found in high-altitude natives of South America when studied in normoxia (28). In 4 subjects the dimensions of the aorta as determined by one-dimensional echocardiography were larger than in 20 untrained control subjects (Table 5). This finding could be the consequence of the greater stroke volume associated with
TABLE 5. One-dimensional echocardiographic data of left heart

\begin{tabular}{lcccccc}
\hline \hline Subj & $\begin{array}{c}\text { LA, } \\
\text { cm }\end{array}$ & $\begin{array}{c}\text { AO, } \\
\text { cm }\end{array}$ & $\begin{array}{c}\text { LV, } \\
\mathrm{cm}\end{array}$ & $\begin{array}{c}\text { Sh, } \% \\
\text { \% }\end{array}$ & $\begin{array}{c}\text { PW, } \\
\mathrm{cm}\end{array}$ & $\begin{array}{c}\mathrm{S}, \\
\mathrm{cm}\end{array}$ \\
\hline$R M$ & 4.0 & 4.0 & 5.8 & 30.0 & 1.00 & 1.00 \\
$M D$ & 4.0 & 4.0 & 5.6 & 41.0 & 1.20 & 1.40 \\
$D S$ & 3.9 & 3.8 & 5.6 & 32.0 & 0.80 & 0.90 \\
$P H$ & 3.2 & 3.2 & 5.6 & 36.0 & 0.90 & 0.90 \\
$H E$ & 3.3 & 4.3 & 5.8 & 33.0 & 0.90 & 0.90 \\
$F M$ & 2.8 & 3.5 & 5.8 & 34.0 & 0.90 & 0.90 \\
& & & & & & \\
Mean & 3.5 & 3.8 & 5.7 & 34.3 & 0.95 & 1.00 \\
\pm SD & \pm 0.5 & \pm 0.4 & \pm 0.1 & \pm 3.8 & \pm 0.14 & \pm 0.20 \\
& & & & & & $<1.2$ \\
\hline
\end{tabular}

LA, diameter of left atrium; AO, diameter of aorta; LV, short diameter of left ventricle; Sh, systolic shortening; PW, posterior wall thickness; $\mathrm{S}$, interventricular septum thickness; normal, see Table 4.

TABLE 6. Fiber type distribution in vastus lateralis muscle

\begin{tabular}{lccc}
\hline \hline Subj & $\begin{array}{c}\text { Type I, } \\
\%\end{array}$ & $\begin{array}{c}\text { Type IIa, } \\
\%\end{array}$ & $\begin{array}{c}\text { Type IIb, } \\
\%\end{array}$ \\
\hline$R M$ & 67.0 & 27.0 & 6.0 \\
$M D$ & 72.0 & 28.0 & 0.0 \\
$D S$ & & & \\
$P H$ & 70.0 & 17.0 & 13.0 \\
$H E$ & 66.0 & 22.0 & 12.0 \\
$F M$ & 76.0 & 18.0 & 6.0 \\
& & & \\
Mean & 70.2 & 22.4 & 7.4 \\
\pm SD & \pm 4.1 & \pm 4.9 & \pm 5.3 \\
& Sedentary $(n=6)$ & \\
Mean & 51.3 & 40.5 & 7.1 \\
土SD & \pm 2.7 & \pm 2.4 & \pm 2.8 \\
& Athletes $(n=9)$ & \\
Mean & 77.9 & 19.3 & 2.5 \\
\pm SD & \pm 2.5 & \pm 3.0 & \pm 0.9 \\
\hline
\end{tabular}

Data for sedentary subjects and athletes from Ref. 21. Values for IIc fibers (not given) make up for the difference to $100 \%$.

bradycardia. The oldest climber $(M D)$ had signs of concentric left ventricular hypertrophy, and another $(P M)$ showed a totally asymptomatic mesotelesystolic prolapse of the mitral valve.

\section{Muscle Fiber Types and Muscle Morphometry}

Muscle fiber types. Vastus lateralis muscle of all the climbers contained a high percentage of type I fibers (Table 6$)$. The mean value $(70.2 \%)$ for this slow-twitch, fatigue-resistant fiber type is well beyond the average of $51 \%$ found with the same technique in sedentary men but lower than the $78 \%$ observed in the best Swiss longdistance runners (21). In two of the subjects the content of fast-twitch, glycolytic type IIb fibers was much higher than expected for athletes of the endurance type.

Muscle morphometry. The mean cross-sectional area of the thigh muscle fibers is significantly smaller in the present group of outstanding climbers than in sedentary men of the same age, and it is only $\sim 50 \%$ of the average fiber area measured in well-trained long-distance runners (Table 7) by the same technique. The number of capil- 
TABLE 7. Morphometry of capillaries and fibers in cross sections of vastus lateralis muscle

\begin{tabular}{|c|c|c|c|c|}
\hline Subj & $\begin{array}{l}N_{\mathrm{N}}(\mathrm{c}, \mathrm{f}), \\
\text { unitless }\end{array}$ & $\begin{array}{c}N_{\mathrm{A}}(\mathrm{c}, \mathrm{f}), \\
\mathrm{mm}^{-2}\end{array}$ & $\begin{array}{l}a(\mathrm{f}), \\
\mu \mathrm{m}^{2}\end{array}$ & $\underset{\mu \mathrm{m}^{2}}{A_{\mathrm{N}}(\mathrm{f}, \mathrm{c})}$ \\
\hline$R M$ & 1.28 & 365 & 3,524 & 2,740 \\
\hline$M D$ & 2.05 & 614 & 3,332 & 1,628 \\
\hline \multicolumn{5}{|l|}{$D S$} \\
\hline$P H$ & 1.29 & 457 & 2,829 & 2,186 \\
\hline$H E$ & 1.77 & 606 & 2,918 & 1,651 \\
\hline$F M$ & 1.97 & 670 & 2,935 & 1,492 \\
\hline Mean & 1.67 & 542 & 3,108 & 1,939 \\
\hline \multirow[t]{2}{*}{$\pm \mathrm{SD}$} & \pm 0.37 & \pm 127 & \pm 303 & \pm 520 \\
\hline & & Sedentary & & \\
\hline \multirow{3}{*}{$\begin{array}{l}\text { Mean } \\
\pm \text { SD }\end{array}$} & 1.39 & $387^{*}$ & $3,640^{*}$ & 2,300 \\
\hline & \pm 0.06 & \pm 25 & \pm 260 & \pm 149 \\
\hline & & Athletes & & \\
\hline Mean & $2.70^{*}$ & 431 & $6,410^{*}$ & 2,320 \\
\hline
\end{tabular}

$N_{\mathrm{N}}(\mathrm{c}, \mathrm{f})$, no. of capillaries per fiber; $N_{\mathrm{A}}(\mathrm{c}, \mathrm{f})$, no. of capillaries per area of tissue; $a(\mathrm{f})$, average area of one fiber; $A_{\mathrm{N}}(\mathrm{f}, \mathrm{c})$, area of tissue perfused by each capillary [reciprocal of $N_{\mathrm{A}}(\mathrm{c}, \mathrm{f})$ ]. Reference values from 5 sedentary men and from 5 well-trained long-distance runners are from Refs. 19 and 36). ${ }^{*}$ Significantly different from climbers (unpaired $t$ test, $2 P<0.05)$.

laries per fiber is slightly larger than the average for sedentary subjects but significantly smaller than for long-distance runners (1.7:2.7). Since the muscle fibers of the climbers are much smaller $\left(3,108 \mu \mathrm{m}^{2}\right)$ than those of untrained subjects $(3,640)$ and of endurance athletes $(6,410)$ (see Table 7 ), this still leads to favorable conditions for tissue oxygenation due to reduction of the diffusion distances.

The volume density of total and interfibrillar mitochondria in vastus lateralis muscle of the climbers is similar to that found by the same method in untrained men of the same age but significantly below the values observed in well-trained long-distance runners (Table 8). These values are consistent with the measurements of $\dot{\mathrm{V}} \mathrm{O}_{2 \text { max }}$ (Table 9), thus confirming the importance of the mitochondrial volume as one of the determinants of the maximum aerobic power in humans (18). In addition, the volume density of mitochondria has been shown to faithfully reflect the activity of the oxidative enzymes of the muscles and particularly of succinate dehydrogenase (29). The volume densities of subsarcolemmal mitochondria and intracellular lipid droplets in the muscles of the climbers are as high as for elite long-distance runners $(18,19)$. Since these variables probably reflect the muscle fiber's capacity to oxidize fat, the present results indicate that outstanding high-altitude climbers during prolonged exercise may rely heavily on fat as energy source during excrcise. The present conclusions from nonacclimatized individuals cannot be applied as such to the conditions of prolonged exposure to high altitude that are known to affect both muscle structure and functions $(3,4)$.

\section{Maximal $\mathrm{O}_{2}$ Consumption and Efficiency of Locomotion}

The peak $\mathrm{Vo}_{2}$ values measured in both series of experiments and the corresponding $\mathrm{HR}$ and maximal $\mathrm{La}_{\mathrm{b}}$ data [ $\left.\hat{L} a_{b}\right]$ are indicated in Table 9 for all subjects. The sixth
TABLE 8. Morphometry of cellular ultrastructure in vastus lateralis

\begin{tabular}{lcccccc}
\hline \hline Subj & $\begin{array}{c}V_{\mathrm{v}}(\mathrm{mc}, \mathrm{f}), \\
\%\end{array}$ & $\begin{array}{c}V_{\mathrm{v}}(\mathrm{ms}, \mathrm{f}), \\
\%\end{array}$ & $\begin{array}{c}V_{\mathrm{v}}(\mathrm{mt}, \mathrm{f}), \\
\%\end{array}$ & $\begin{array}{c}V_{\mathrm{v}}(\mathrm{li}, \mathrm{f}), \\
\%\end{array}$ & $\begin{array}{c}V_{\mathrm{v}}(\mathrm{fi}, \mathrm{f}), \\
\%\end{array}$ & $\begin{array}{c}V_{\mathrm{v}}(\mathrm{re}, \mathrm{f}), \\
\%\end{array}$ \\
\hline$R M$ & 4.61 & 0.79 & 5.41 & 0.12 & 76.26 & 17.15 \\
$M D$ & 4.36 & 1.11 & 5.46 & 0.59 & 78.78 & 15.16 \\
$D S$ & & & & & & \\
$P H$ & 3.89 & 0.64 & 4.53 & 1.73 & 78.28 & 15.47 \\
$H E$ & 4.32 & 0.46 & 4.78 & 1.11 & 82.03 & 12.08 \\
$F M$ & 3.85 & 0.71 & 4.56 & 0.61 & 81.39 & 13.45 \\
& & & & & & \\
Mean & 4.21 & 0.74 & 4.95 & 0.83 & 79.35 & 14.66 \\
\pm SD & \pm 0.33 & \pm 0.24 & \pm 0.46 & \pm 0.61 & \pm 2.36 & \pm 1.95 \\
& & & Sedentary & & & \\
Mean & 4.25 & 0.48 & 4.74 & 0.68 & $82.79^{*}$ & 10.57 \\
\pm SD & \pm 0.26 & \pm 0.07 & \pm 0.30 & \pm 0.17 & \pm 2.36 & \pm 3.74 \\
& & \multicolumn{7}{c}{ Athletes } & & & \\
Mean & $6.57^{*}$ & 0.74 & $7.32^{*}$ & 0.85 & $82.97^{*}$ & $8.86^{*}$ \\
\pm SD & \pm 1.00 & \pm 0.42 & \pm 0.89 & \pm 0.41 & \pm 2.18 & \pm 1.15 \\
\hline
\end{tabular}

$V_{\mathrm{v}}(\mathrm{mc}, \mathrm{f})$, volume density of interfibrillar mitochondria; $V_{\mathrm{v}}(\mathrm{ms}, \mathrm{f})$, volume density of subsarcolemmal mitochondria; $V_{v}(\mathrm{mt}, \mathrm{f})$, volume density of total mitochondria; $V_{v}(l i, f)$, volume density of intracellular lipid droplets; $V_{\mathrm{v}}(\mathrm{fi}, \mathrm{f})$, volume density of myofibrils; $V_{\mathrm{v}}(\mathrm{re}, \mathrm{f})$, volume density of residual sarcoplasmic components. Reference values from 5 sedentary men and 5 well-trained long distance runners are from Refs. 18 and 19. * Significantly different from climbers (unpaired $t$ test, 2 $P<0.05)$

TABLE 9. $\mathrm{O}_{2}$ uptake, heart rates, and peak lactate concentrations from two different treadmill tests

\begin{tabular}{|c|c|c|c|c|c|c|}
\hline \multirow[b]{2}{*}{ Subj } & \multicolumn{2}{|c|}{ Run $10 \%$ Grade } & \multicolumn{2}{|c|}{ Walk $35 \%$ Grade } & \multirow[b]{2}{*}{$\begin{array}{c}\dot{\mathrm{V}} \mathrm{O}_{2 \max } \\
\mathrm{ml} \cdot \mathrm{min}^{-1} \cdot \mathrm{kg}^{-1}\end{array}$} & \multirow[b]{2}{*}{$\begin{array}{c}{\left[\hat{L} a_{b}\right]} \\
m M\end{array}$} \\
\hline & $\begin{array}{c}\dot{\mathrm{VO}}_{2} \\
\mathrm{ml} \cdot \mathrm{min}^{-1} \\
\mathrm{~kg}^{-1}\end{array}$ & $\begin{array}{l}\mathrm{HR}, \\
\mathrm{min}^{-1}\end{array}$ & $\begin{array}{c}\dot{\mathrm{VO}}_{2} \\
\mathrm{ml} \cdot \mathrm{min}^{-1} \\
\mathrm{~kg}^{-1}\end{array}$ & $\begin{array}{l}\mathrm{HR}, \\
\min ^{-1}\end{array}$ & & \\
\hline$R M$ & 48.8 & 184.0 & 46.6 & 161.0 & 48.8 & 15.3 \\
\hline$M D$ & 60.8 & 192.0 & 57.0 & 180.0 & 60.8 & 12.2 \\
\hline$D S$ & 57.0 & 181.0 & 63.0 & 174.0 & 63.0 & 15.1 \\
\hline$P H$ & 65.9 & 182.0 & 55.4 & 172.0 & 65.9 & 12.8 \\
\hline$H E$ & 54.5 & 195.0 & 56.1 & 185.0 & 56.1 & 7.2 \\
\hline$F M$ & 62.5 & 203.0 & 58.0 & 187.0 & 62.5 & 8.6 \\
\hline $\begin{array}{l}\text { Mean } \\
\pm S D\end{array}$ & 58.3 & 189.5 & 56.0 & 176.5 & 59.5 & 11.9 \\
\hline$\pm \mathrm{SD}$ & \pm 6.1 & \pm 8.7 & \pm 5.3 & \pm 9.6 & \pm 6.2 & \pm 3.3 \\
\hline
\end{tabular}

$\dot{\mathrm{V}} \mathrm{O}_{2}$, peak $\mathrm{O}_{2}$ consumption; $\mathrm{HR}$, peak heart rate; $\dot{\mathrm{V}} \mathrm{O}_{2 \max }$, maximal $\mathrm{O}_{2}$ consumption; $\left[\hat{\mathrm{L}} \mathrm{a}_{\mathrm{b}}\right]$, maximal blood lactate concentration at exhaustion. $2 P$ by paired $t$ test.

column in Table 9 indicates the highest measured $\mathrm{V}_{2}$, which will be considered from now on as the subjects' $\dot{\mathrm{V}} \mathrm{O}_{2}$ max. These values are reported as a function of the subjects' age, together with the literature data for sedentary subjects (1), alpine guides (Cerretelli, unpublished observation), and amateur and elite long-distance runners $(9,13)$ in Fig. 1.

The average values for mechanical efficiency amount to $0.249 \pm 0.009$ (SD; 22 observations in 6 subjects) for walking and to $0.167 \pm 0.012$ (25 observations in 5 subjects) for running. The peak $\mathrm{V}_{2}{ }^{\prime}$ 's observed in walking (on a $+35 \%$ grade) and in running (on a $+10 \%$ grade) in two different laboratories are essentially the same, a fact reflected by the small and statistically nonsignificant difference between the two means. On the contrary, the peak HR's are significantly higher during the 


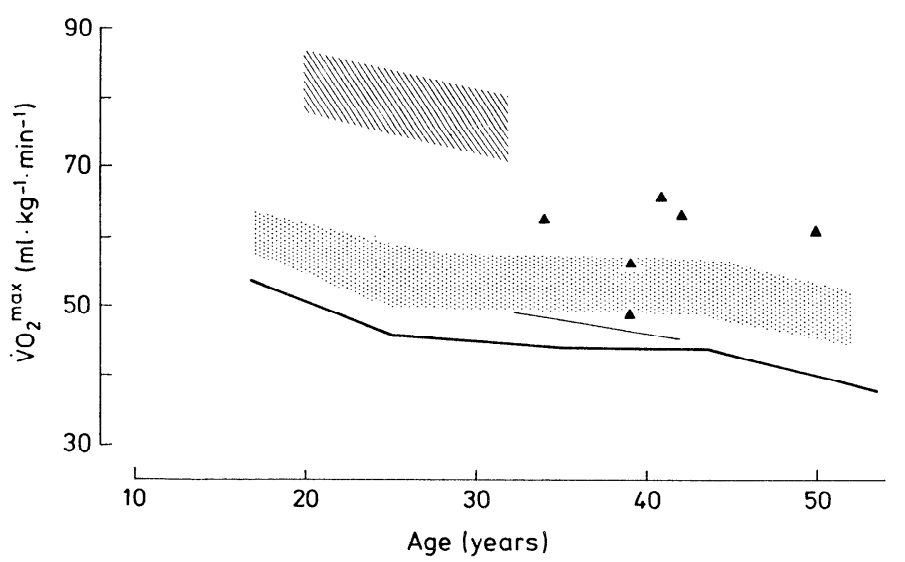

FIG. 1. Maximal $\mathrm{O}_{2}$ consumption $\left(\mathrm{V}_{\mathrm{O}_{2 m a x}}\right)$ as a function of age. Filled triangles, present data on elite climbers; dotted area, amateur marathoners (from Ref. 13); thick line, sedentary controls (from Ref. 1); thin line, professional alpine guides (Cerretelli, unpublished data); hatched area, elite marathoners (from Ref. 9).

running measurement, a fact that depends presumably on the different exercise mode. Finally, [L $\left.\mathrm{L}_{b}\right]$ at exhaustion ranged from 7 to $15 \mathrm{mM}$, thus indicating that, as far as the anaerobic lactic capacity is concerned, this group of elite mountain climbers cannot be differentiated from nonathletic, moderately trained individuals.

The $\dot{\mathrm{V}} \mathrm{O}_{2}$ max values of elite climbers (Table 9, Fig. 1), even though higher than those observed in untrained subjects (1) of the same age, fall within the range for amateur marathon runners (13) but are well below the values of elite long-distance runners (9).

During short submaximal exercise below the anaerobic threshold, i.e., at a $\dot{\mathrm{VO}}_{2}$ equal to 53 and $76 \%$ of $\dot{\mathrm{VO}}_{2 \text { max }}$, the mean respiratory exchange ratio of the climbers was 0.92 and 0.96 , respectively. These values are not different from the average values obtained at the same relative work load in the control subjects.

The mechanical efficiency data calculated for uphill walking and running (see above) are the same as observed in these forms of locomotion on the same slopes for sedentary untrained subjects $(23,24)$. These observations can obviously not be extended to actual climbing. Indeed, the inborn skill and enormous experience of these individuals allow them to move in difficult mountain terrain in a most economical fashion. This may be illustrated by the legendary speed of descent of two of these subjects. In 1978, PH descended from the summit of Mt. Everest to the South Col, i.e., $860 \mathrm{~m}$, in $1 \mathrm{~h}$, and later in the same year $R M$ descended the most difficult Nanga Parbat Diamir face from 7,200 to $4,000 \mathrm{~m}$ in $3.5 \mathrm{~h}$ !

It can be concluded that the maximal aerobic power, the fraction of mobilized oxidative substrates at submaximal exercise, the lactic capacity, and the efficiency of locomotion of this group of elite mountain climbers as assessed in the laboratory are essentially the same as observed in nonathletic well-trained subjects. Moreover, no relationship whatsoever between individual climbing technical level and $\dot{V}_{O_{2}}$ max was found within the group: indeed the most successful climber $(R M)$ was characterized by the lowest $\dot{\mathrm{V}}_{2}$ max. In this connection, it is interesting to note that according to $R M$ it took him $1 \mathrm{~h}$ to climb the last $100 \mathrm{~m}$ of Mt. Everest (25). The corresponding power output against gravity amounted to 0.27
$\mathrm{W} \cdot \mathrm{kg}^{-1}$, i.e., to $18.4 \mathrm{~W}$ for $68-\mathrm{kg}$ total weight $(60 \mathrm{~kg}$ of body wt $+8 \mathrm{~kg}$ of equipment). If a caloric equivalent of $\mathrm{O}_{2}$ of $20.9 \mathrm{~kJ} \cdot \mathrm{l}^{-1}$ (at a $\mathrm{RQ}=0.96$ ) and an overall efficiency of locomotion of $10 \%$ are assumed, this implies a $\dot{\mathrm{V}} \mathrm{O}_{2}$ of $530 \mathrm{ml} \cdot \mathrm{min}^{-1}$ above resting, i.e., of $\sim 800 \mathrm{ml}$. $\mathrm{min}^{-1}$ total. This corresponds to $75-80 \%$ of the $\dot{\mathrm{V}} \mathrm{O}_{2 \text { max }}$ value of $1.07 \mathrm{l} \cdot \mathrm{min}^{-1}$ measured by West (34) in wellacclimatized subjects at $6,300 \mathrm{~m}$ while they were breathing a gas mixture with $\mathrm{PI}_{\mathrm{O}_{2}}$ of 43 Torr, equivalent to that on the Everest summit, and to $\sim 20 \%$ of the sea-level values determined on $R M$ and $R H$ in the present study (Tables 2 and 9). The above calculated values of $\dot{V} \mathrm{O}_{2}$ during altitude climbing may be overestimates due to 1 ) the time for the last 100 -m vertical displacement is not precisely known and is presumably somewhat longer than $1 \mathrm{~h}$ and 2) the $\dot{\mathrm{V}} \mathrm{O}_{2 \text { max }}$ of $R M$ and $\mathrm{PH}$ at the time of the climb may have been slightly higher than in the present study. The $\dot{\mathrm{V}}_{2}$ levels calculated for the present elite climbers are also compatible with the $\dot{\mathrm{V}} \mathrm{O}_{2}$ max values estimated by Sutton et al. (32) based on climbing speeds.

\section{Maximal Anaerobic Power}

The $\dot{\mathrm{w}}_{\max }$ values determined on the six mountaineers and four control subjects are shown in Fig. 2, together with values for young sedentary males and females, al-

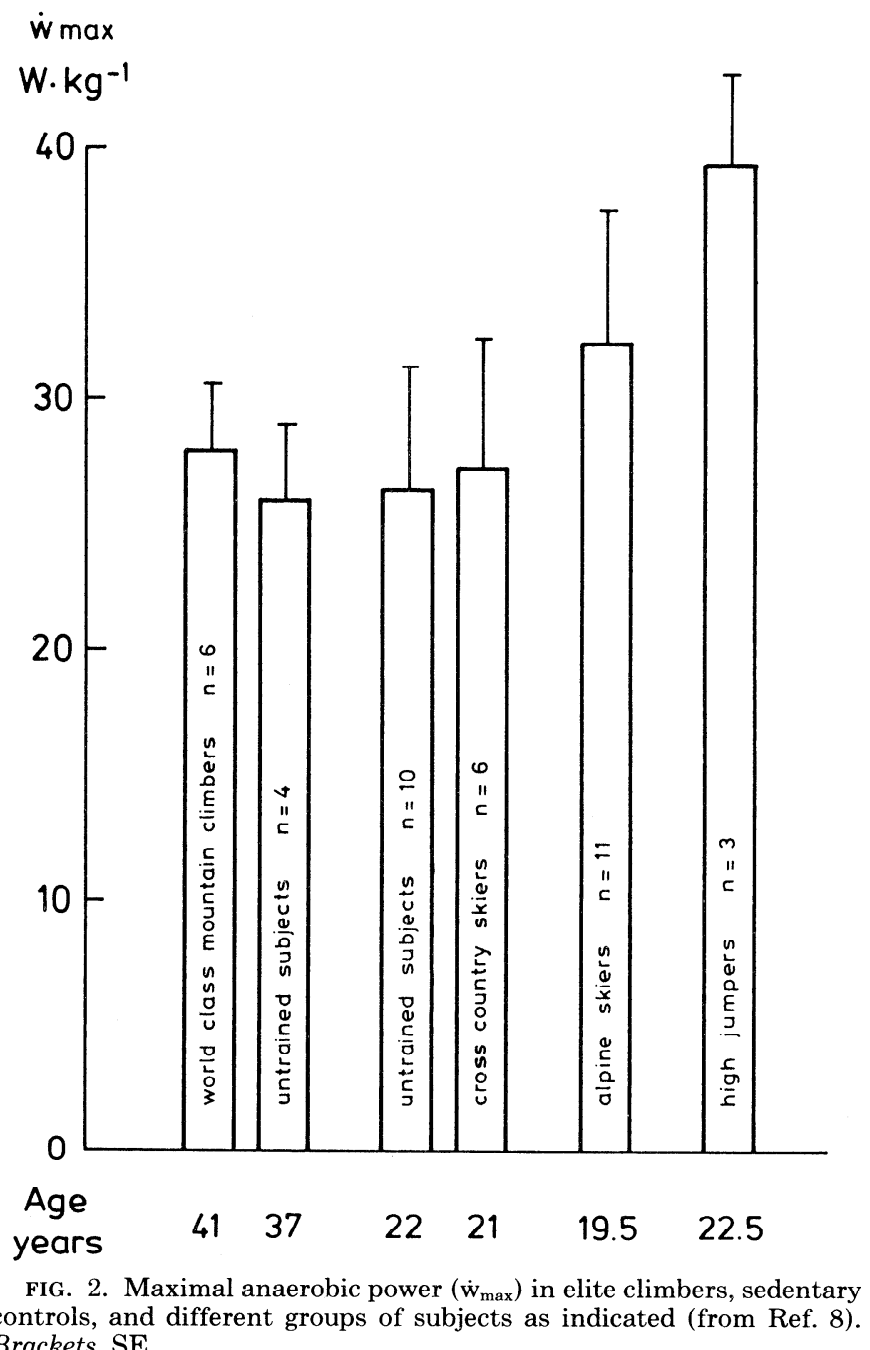


TABLE 10. Pulmonary ventilation, oxyhemoglobin saturation, and heart rate and changes following four tidal volumes of pure $\mathrm{O}_{2}$

\begin{tabular}{|c|c|c|c|c|c|c|c|}
\hline \multicolumn{4}{|c|}{ Normoxia } & \multicolumn{4}{|c|}{ Hypoxia $\left(\mathrm{PI}_{\mathrm{O}_{2}}=77\right.$ Torr $)$} \\
\hline \multicolumn{2}{|c|}{ Elite climbers } & \multicolumn{2}{|c|}{ Controls } & \multicolumn{2}{|c|}{ Elite climbers } & \multicolumn{2}{|c|}{ Controls } \\
\hline$\dot{\mathrm{V} E}$ & $\Delta \dot{\mathbf{V}} \mathbf{E}$ & $\dot{\mathrm{V} E}$ & $\Delta \dot{\mathrm{VE}}$ & $\dot{\mathrm{V}} \mathrm{E}$ & $\Delta \dot{\mathrm{V}} \mathrm{E}$ & $\dot{\mathrm{V}} \mathrm{E}$ & $\Delta \dot{V}_{\mathrm{E}}$ \\
\hline \multicolumn{8}{|c|}{$\begin{array}{c}\text { A. Pulmonary Ventilation } \\
\text { Rest }\end{array}$} \\
\hline $\begin{array}{l}15.2 \pm 6.6 \\
26.3-7.9\end{array}$ & $\begin{array}{l}-16.8 \pm 11.1 \\
-28.0 \text { to } 4.0\end{array}$ & $\begin{array}{l}7.3 \pm 0.8 \\
8.4-6.4\end{array}$ & $\begin{array}{l}-15.9 \pm 4.2 \\
-21.7 \text { to }-12.0\end{array}$ & $\begin{array}{l}14.3 \pm 3.2 \\
18.8-12.4\end{array}$ & $\begin{array}{l}-26.6 \pm 15.2 \\
-45.0 \text { to }-8.0\end{array}$ & $\begin{array}{c}10.6 \pm 0.3 \\
11.3-10.3\end{array}$ & $\begin{array}{l}-42.5 \pm 11.5 \\
-56.0 \text { to }-30.0\end{array}$ \\
\hline \multicolumn{8}{|c|}{ Exercise, $90 \mathrm{~W}$ (cycle) } \\
\hline $\begin{array}{l}32.1 \pm 5.2 \\
38.8-28.4\end{array}$ & $\begin{array}{l}-22.8 \pm 11.7 \\
-35.6 \text { to }-5.6\end{array}$ & $\begin{array}{l}23.8 \pm 4.7 \\
28.7-18.4\end{array}$ & $\begin{array}{l}-19.3 \pm 15.2 \\
-45.0 \text { to }-4.0\end{array}$ & $\begin{array}{l}40.2 \pm 7.3 \\
54.0-34.4\end{array}$ & $\begin{array}{l}-52.2 \pm 17.5 \\
-68.0 \text { to }-25.0\end{array}$ & $\begin{array}{l}42.4 \pm 2.4 \\
48.8-40.5\end{array}$ & $\begin{array}{l}-53.0 \pm 10.1 \\
-70.0 \text { to }-40.0\end{array}$ \\
\hline $\mathrm{HbO}_{2}$ & $\Delta \mathrm{HhO}_{2}$ & $\mathrm{HbO}_{2}$ & $\Delta \mathrm{HbO}_{2}$ & $\mathrm{HbO}_{2}$ & $\Delta \mathrm{HbO}_{2}$ & $\mathrm{HbO}_{2}$ & $\Delta \mathrm{HbO}_{2}$ \\
\hline \multicolumn{8}{|c|}{$\begin{array}{c}\text { B. Oxyhemoglobin Saturation } \\
\text { Rest }\end{array}$} \\
\hline \multicolumn{8}{|c|}{ Exercise, $90 \mathrm{~W}$ (cycle) } \\
\hline $\begin{array}{l}97.2 \pm 0.9 \\
98.1-95.9\end{array}$ & $\begin{array}{r}2.1 \pm 0.7 \\
2.8-0.9\end{array}$ & $\begin{array}{l}97.8 \pm 1.1 \\
99.0-96.6\end{array}$ & $\begin{array}{c}2.2 \pm 1.2 \\
3.4-1.0\end{array}$ & $\begin{array}{l}75.4 \pm 9.9 \\
92.6-66.0\end{array}$ & $\begin{array}{c}24.0 \pm 10.0 \\
33.9-6.7\end{array}$ & $\begin{array}{l}69.3 \pm 2.8 \\
73.7-65.9\end{array}$ & $\begin{array}{l}29.6 \pm 2.9 \\
33.0-25.2\end{array}$ \\
\hline HR & $\Delta \mathrm{HR}$ & HR & $\Delta \mathrm{HR}$ & HR & $\Delta \mathrm{HR}$ & $\mathrm{HR}$ & $\Delta \mathrm{HR}$ \\
\hline \multicolumn{8}{|c|}{$\begin{array}{l}\text { C. Heart Rate } \\
\text { Rest }\end{array}$} \\
\hline $\begin{array}{c}75.2 \pm 14.2 \\
94-61\end{array}$ & $\begin{array}{l}-1.9 \pm 9.4 \\
-13.3 \text { to } 9.7\end{array}$ & $\begin{array}{l}72.8 \pm 17.9 \\
92-57\end{array}$ & $\begin{array}{l}-13.9 \pm 12.0 \\
-30.2 \text { to }-1.7\end{array}$ & $\begin{array}{c}85.8 \pm 13.9 \\
98-68\end{array}$ & $\begin{array}{l}-18.7 \pm 13.3 \\
-32.7 \text { to } 0.0\end{array}$ & $\begin{array}{l}91.3 \pm 11.8 \\
102-76\end{array}$ & $\begin{array}{l}-23.6 \pm 5.7 \\
-31.7 \text { to }-17.6\end{array}$ \\
\hline \multicolumn{8}{|c|}{ Exercise, $90 \mathrm{~W}$ (cycle) } \\
\hline
\end{tabular}

Values are means $\pm \mathrm{SD}$ with ranges helow. $\dot{\mathrm{V}} \mathrm{E}$, pulmonary ventilation $\left(1 \cdot \mathrm{min}^{-1}, \mathrm{BTPs}\right) ; \Delta \dot{\mathrm{V}}$, $\dot{\mathrm{V}} \mathrm{E}$ changes $(\%) ; \mathrm{HbO}{ }_{2}$, oxyhemoglobin saturation (\%); $\Delta \mathrm{HbO}_{2}, \mathrm{HbO}_{2}$ changes (\%); $\mathrm{HR}$, heart rate $\left(\mathrm{min}^{-1}\right) ; \Delta \mathrm{HR}, \mathrm{HR}$ changes $(\%)$.

pine skiers, and high jumpers (8).

The average $\dot{\mathrm{w}}_{\max }$ of $28.3 \pm 2.5(\mathrm{SD}) \mathrm{W} \cdot \mathrm{kg}^{-1}$ found in elite climbers is essentially equal to that observed on sedentary subjects (Fig. 2). For comparison, high jumpers are characterized by a $40 \%$ higher $\dot{\mathrm{w}}_{\max }$ value (8). Since $\dot{\mathrm{w}}_{\max }$ may be an indicator of the maximal rate of phosphocreatine splitting (12), it may be concluded that the group of elite climbers does not differ substantially from nonathletic trained subjects. This finding is compatible with the low percentage of type II fibers found in these subjects (see Table 6).

\section{Ventilalory Control, Oxyhemoglobin Saturation, and Heart Rate}

The results of the study of the chemoreflex control of ventilation indicate first of all that (Table 10A) resting $\dot{V} E$ is higher in elite climbers than in control subjects, both in normoxia $\left(15.2 \pm 2.7\right.$ vs. $7.3 \pm 0.4 \mathrm{l} \cdot \mathrm{min}^{-1}$ with corresponding $\mathrm{PET}_{\mathrm{CO}_{2}}$ values of $28.2 \pm 2.8$ vs. $35.1 \pm 2.9$ Torr, respectively) and acute hypoxia ( $14.3 \pm 1.3$ vs. 10.6 $\pm 0.5 \mathrm{l} \cdot \mathrm{min}^{-1}$ with corresponding $\mathrm{PET}_{\mathrm{CO}_{2}}$ values of 28.7 \pm 2.5 vs. $33.5 \pm 1.5$ Torr, respectively). This observation is in agreement with previous findings by Schoene et al.
(31), who observed that among the climbers of the American Medical Research Expedition to Mt. Everest, the summiters were characterized by resting hyperventilation and by the greater ventilatory response to hypoxia. This is probably the consequence of a persisting ventilatory acclimatization. The ventilatory response to exercise in normoxia is essentially the same in the two groups. In hypoxic exercise, however, the ventilatory response of the climbers is somewhat higher, as shown by the mean $\mathrm{PET}_{\mathrm{CO}_{2}}$ values (37.3 vs. 42.5 in the climbers and the controls, respectively). With regard to the ventilatory control, the only significant difference between elite climbers and sedentary subjects is a marked resting hyperventilation and increased sensitivity to moderate hypoxia observed in the former (see Table 10A). During hypoxic exercise, following sudden bursts of hyperoxia, the decrease of ventilation $(\Delta \dot{\mathrm{V} E})$ is more pronounced and equal for the two groups $(\sim-50 \%)$ which confirms previous observations by Dejours et al. (11) and Cerretelli (6). In normoxia, $\Delta \dot{V} E$ is less relevant and the climbers were not different from controls. The transient changes of $\mathrm{PET}_{\mathrm{CO}_{2}}$ were essentially the mirror image of those of $\dot{V} E$ and therefore are not reported. In essence, the ventilatory response to both acute hypoxia and exercise as 
well as to burst of hyperoxia is essentially the same in elite climbers and controls. It cannot be excluded, however, that the results of the present experimental protocol may differ substantially between the two groups at the end of the acclimatization process which may be characterized in the climbers by some peculiar feature. The ventilatory results appearing in Table $10 \mathrm{~A}$ support previous findings showing that elite mountain climbers are characterized by greater ventilation. Schoene (30) found a higher resting ventilation and a more pronounced ventilatory response to hypoxia and hypercapnia in a group of mountaineers at sea level which lead them to conclude that "climbers to extreme altitude may be a group of athletes in whom a brisk ventilatory response to hypoxia is helpful for survival and successful performance in this environment."

From Table $10 B$ it appears that the drop in $\% \mathrm{HbO}_{2}$ at $\mathrm{PI}_{\mathrm{O}_{2}}=77$ Torr is markedly less at rest in the climbers (98.1 vs. 88.8) than in the controls (98.5 vs. 78 ). However, during exercise the climbers are not statistically different from the controls ( 75.4 vs. 69.3 ). It is noteworthy that one of the subjects, probably the most outstanding $(R M)$, had still a $\% \mathrm{HbO}_{2}$ of 92.8 when exercising at $90 \mathrm{~W}$ in acute hypoxia.

Following the administration of four breaths of $\mathrm{O}_{2}$, a slight chemoreflex bradycardia $(\Delta \mathrm{HR}$, see Table $10 C)$ is elicited in normoxia, both at rest and exercise, particularly in the controls. In hypoxia, $\Delta \mathrm{HR}$ was more marked than in normoxia, with no difference being found between climbers and controls.

\section{Conclusions}

The physiological profile of a world-class altitude climber as found in the present study is that of a normal endurance-trained individual, as shown by 1) the microscopic muscle structure characterized by an accumulation of subsarcolemmal mitochondria, a relative abundance of fat droplets between myofibrils, and a favorable geometry for blood-tissue gas exchange (see Table 7) and 2 ) the maximal aerobic and anaerobic power and capacity that do not differ substantially from those of active nonathletic subjects. As far as $\dot{V}_{O_{2} \text { max }}$ and muscular efficiency is concerned, Caucasian elite climbers are not different from altitude Sherpas as previously shown by Cerretelli (7).

An observation that may have some relevant bearings on the performance characteristics of outstanding altitude climbers appears to be their $\% \mathrm{HbO}_{2}$ value, which for a given drop of $\mathrm{PI}_{\mathrm{O}_{2}}$ appears to be higher than in control subjects. In the case of subject $R M$, for example, for a $\mathrm{PI}_{\mathrm{O}_{2}}$ of 77 Torr and a work load of $90 \mathrm{~W}, \% \mathrm{HbO}_{2}$ was 92.6 compared with an average value of 69.3 for the controls and of 75.4 for the whole group of climbers. This finding could possibly be explained with a greater lung diffusing capacity for $\mathrm{O}_{2}$ that might be a peculiar characteristic of elite altitude mountaineers. This problem is still a matter for investigation.

On the whole, it appears that the main features of a successful elite altitude climber are, besides an optimal functional balance and an unusual skill, strong motiva- tion and exceptional drive. Reinhold Messner, the first mountaineer to overcome the barrier of $8,500 \mathrm{~m}$ without supplemental $\mathrm{O}_{2}$, really typifies these climbers. He is characterized by rather normal physiological features but by the obsessive need to be the first and the best, by "fair means" as he states it, i.e., without the aid of $\mathrm{O}_{2}$ in any phase of the ascent.

It appears reasonable to suggest that a skilled climber also characterized by a very high $\dot{\mathrm{V}} \mathrm{O}_{2 \text { max }}$ such as that of a top marathoner, may perform, ceteris paribus, better than even the best of the present climbers. This obviously requires that the athletic physiological background not be counterbalanced by a labile personality as often found among endurance runners (15).

The authors are indebted to Dr. Sukhamay Lahiri for suggesting the experimental protocol for chemoreflex testing and to Dr. John B. West for constructive criticism.

This study was supported by the EMDO-Stiftung and by Grants $3.332 .78,3.128 .0 .81$, and 3.364.0.82 of the Swiss National Research Foundation (FNRS).

Address for reprint requests: O. Oelz, Dept. of Medicine, University Hospital, CH-8091 Zurich, Switzerland.

Received 17 June 1985; accepted in final form 5 December 1985.

\section{REFERENCES}

1. Åstrand, P.-O., And E. H. Christensen. Aerobic work capacity. In: Oxygen in the Animal Organism, edited by F. Dickens, E. Neil, and W. F. Widdas. New York: Pergamon, 1964, p. 295-303.

2. Bommer, W., L. Weinert, A. Neumann, J. Neef, D. T. Mason, AND A. DE MARIA. Determination of right atrial and right ventricular size by two-dimensional echocardiography. Circulation 60: 91$100,1979$.

3. Bouttelilier, U., H. Howald, P. E. di Prampero, D. GiezenDANNER, AND P. Cerretelli. Human muscle adaptations to chronic hypoxia. In: Hypoxia, Exercise and Altitude: Proceedings of the Third Banff International Hypoxia Symposium, edited by J. R. Sutton, C. S. Houston, and N. L. Jones. New York: Liss, 1983, p. 273-281.

4. Boyer, S. J., AND F. D. Blume. Weight loss and changes in body composition at high altitude. J. Appl. Physiol. 57: 1580-1585, 1984.

5. Buehlmann, A. A., AND M. Scherrer. Neue Normalverte für die Vital- und Totalkapazität der Lungen. Schweiz. Med. Wochenschr. 103: 660-668, 1973.

6. Cerretelli, P. Esistenza di una permanente stimolazione ipossica del centro respiratorio in individui acclimatati a quote di 5000 7500 m. s.l.m. (Himalaya). Atti Congr. Int. Med. Aeron. Spaziale. Roma 1959, p. 1-8.

7. Cerretelli, P. Gas exchange at high altitude. In: Pulmonary Gas Exchange, edited by J. B. West. New York: Academic, 1980, vol. II, p. 97-147.

8. Cerretelli, P., P. Mognoni, and C. Marconi. Aerobic and anaerobic metabolism in health and disease: the role of training. Ann. Clin. Res. 14, Suppl. 34: 12-19, 1982.

9. Costill, D. L., W. J. Fink, and M. L. Pollock. Muscle fiber composition and enzyme activities of elite distance runners. Med. Sci. Sports 8: 96-100, 1976.

10. Davies, C. T. M., AND R. RenNie. Human power output. Nature Lond. 217: 770-771, 1968.

11. Derours, P., F. Girard, Y. Labrousse, and A. Teitliac. Etude de la régulation de la ventilation de repos chez l'homme en haute altitude. Rev. Franc. Etud. Clin. Biol. 4: 115-127, 1959.

12. Di Prampero, P. E. Energetics of muscular exercise. Rev. Physiol. Biochem. Pharmacol. 89: 143-222, 1981.

13. Di Prampero, P. E., G. Atchou, J.-C. Brueckner, and C. Moia. The energetics of endurance running. Eur. J. Appl. Physiol. Occup. Physiol. In press.

14. Feigenbaum, H. Echocardiography. Philadelphia, PA: Lea \& Febiger, 1976, vol. 2 . 
15. Gontang, A., T. Clitsome, and T. Kostrubala. A psychological study of 50 sub-3-hour marathoners. Ann. NY Acad. Sci. 301: 10201028, 1977.

16. HABELER, P. Everest: Impossible Victory. London: Arlington, 1979.

17. HacketT, P. H., D. Rennie, S. E. Hofmeister, R. F. Grover, E. B. Grover, and J. T. Reeves. Fluid retention and relative hypoventilation in acute mountain sickness. Respiration 43: 321$329,1982$.

18. Hoppeler, H., H. Howald, K. Conley, St. L. Lindstedt, H. ClaAssen, P. VoCK, AND E. R. Weibel. Endurance training in humans: aerobic capacity and structure of skeletal muscle. J. Appl. Physiol. 59: 320-327, 1985.

19. Hoppeler, H., P. LUthi, H. Claassen, E. R. Weibeil, and H. How ALD. The ultrastructure of the normal human skeletal muscle; a morphometric analysis of untrained men, women, and welltrained orienteers. Pfluegers Arch. 344: 217-232, 1973.

20. Houston, C. S. Operation Everest, a study of acclimatization to anoxia. US Naval Med. Bull. 46: 1783, 1946.

21. Howald, H. Training-induced morphological and functional changes in skeletal muscle. Int. J. Sport Med. 3: 1-12, 1982.

22. JenNi, R., N. Göbel, L. Schneider, AND H. P. KRAYenbÜhl. Familiäre idiopathische Dilatation des rechten Vorhofes. Schweiz. Med. Wochenschr. 111: 1565-1572, 1981.

23. Margaria, R. Sulla fisiologia e specialmente sul consumo energetico della marcia e della corsa a varia velocità ed inclinazione del terreno. Atti Reale Acc. Naz. Lincei 7: 299-368, 1938.

24. Margaria, R., P. Cerretelli, P. Aghemo, and G. Sassi. Energy cost of running. J. Appl. Physiol. 18: 367-370, 1963.

25. Messner, R. Everest: Expedition to Ultimate. London: Kay \& Ward, 1979.

26. Nok'Ton, E. F. Norton and Somervell's attempt. In: The Fight for Everest. London: Arnold, 1925, p. 108-113.
27. Panykula, H. A., and F. Herman. The specificity of the histochemical method of adenosine triphosphatase. J. Histochem. Cytochem. 3: 170-195, 1955.

28. Peñaloza, D., F. Sime, N. Banchero, and R. Gamboa. Pulmonary hypertension in healthy man born and living at altitudes. Med. Thorac. 19: 449-460, 1962.

29. Reichmann, H., H. Hoppeler, O. Mathieu-Costello, F. Von BERGEN, AND D. PETTE. Biochemical and ultrastructural changes of skeletal muscle mitochondria after chronic electrical stimulation in rabbits. Pfluegers Arch. 404: 1-9, 1985.

30. Schoene, R. B. Control of ventilation in climbers to extreme altitude. J. Appl. Physiol. 53: 886-890, 1982.

31. Schoene, R. B., S. Lahiri, P. H. Hackett, R. M. Peters, JR., J. S. Milledge, C. J. Pizzo, F. H. SARnquist, S. J. Boyer, D. J. Graber, K. H. Maret, AND J. B. West. Relationship of hypoxic ventilatory response to exercise performance on Mount Everest. $J$. Appl. Physiol. 56: 1478-1483, 1984.

32. Sutton, J. R., N. L. Jones, And L. G. C. E. Pugh. Exercise at altitude. Annu. Rev. Physiol. 45: 427-437, 1983.

33. Weibel, E. R. Stereological methods. In: Practical Methods for Biological Morphometry. London: Academic, 1979, vol. 1.

34. WEST, J. B. Climbing Mt. Everest without oxygen: an analysis of maximal exercise during extreme hypoxia. Respir. Physiol. 52: 265$279,1983$.

35. West, J. B., P. H. Hackett, K. H. Maret, J. S. Milledge, R. M. Peters, JR., C. J. Pizzo, ANd R. M. Winslow. Pulmonary gas exchange on the summit of Mount Everest. J. Appl. Physiol. 55: 678-687, 1983.

36. Zumstein, A., O. Mathieu, H. Howald, and H. Hoppeler. Morphometric analysis of the capillary supply in skeletal muscles of trained and untrained subjects. Its limitation in muscle biopsies. Pfluegers Arch. 397: 277-283, 1983.

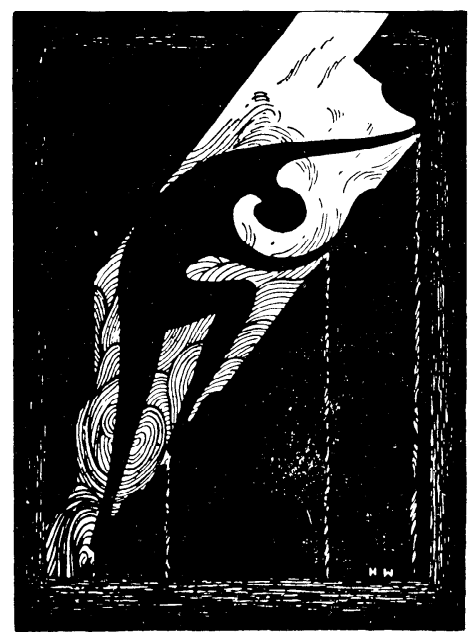

